\title{
PENINGKATAN KEMAMPUAN MANAJEMEN PEMASARAN COFFEE SHOP DAN NILAI TAMBAH PANGAN BERBAHAN BAKU KOPI DI KOPERASI PRODUSEN KOPI MARGAMULYA (KPKM)
}

\author{
Tuti Karyani ${ }^{1}$, Endah Djuwendah ${ }^{2}$, Kuswrini Kusno ${ }^{3}$, dan Nurul Risti $\mathbf{M}^{4}$ \\ ${ }^{1-3}$ Fakultas Pertanian, Universitas Padjadjaran \\ ${ }^{4}$ Universitas Siliwangi \\ E-mail: tuti.karyani@unpad.ac.id
}

\begin{abstract}
ABSTRAK. Saat ini bisnis warung kopi bermunculan di mana-mana karena pemintaan dan kebiasaaan ngopi di kafe/warung kopi untuk berkumpul bersama teman-teman, keluarga maupun sekedar gaya hidup sedang melanda negerii ini untuk semua kalangan terutama anak mudanya. Untuk menangkap peluang ini maka Koperasi Produsen Kopi Margamulya (KPKM) membuka unit bisnis warung kopi (kafe) dengan nama Warung Kopi Gunung Tilu. Selain itu dengan dibukanya unit usaha warung kopi terbuka bagi ibuibu petani kopi untuk menitipkan produk turunan dari kopi baik makanan maupn non makanan. Oleh karena itu dirasakan perlu pelatihan manajemen pemasarann warung kopi agar kafe bisa bersaing dan berkelanjutan, Demikian juga perlu pelatihan untuk ibuibu tani mengenai peningkatan nilai tambah produk kopi . Metode yang dilakukan adalah pemberdayaan partisipatif, yang meliputi pelatihan, mentoring, monitoring dan evaluasi dengan sasarannya adalah pengelola Warung kopi (kafe) Gunung Tilu dan ibu-ibu tani dan remaja putri petani kopi. Langkah pertama dilakukan penelusuran informasi untuk kegiatan yang akan dibuat seperti perlunya peningkatan nilai tambah dari kopi.serta pengelolaan warung kopi berunsur edukasi. Selanjutnya beberapa kali diberikan materi dan pelatihan keterampilan peningkatan nilai tambah yang mendatangkan nara sumber selain dari dosen dan mahasiswa serta pemberian pengetahuan tentang penggunaan media social (medso) sebagai fasilitas untuk promosi dan materi mengenai pembuatan poster berunsur edukasi. Hasil evaluasi menunjukan pelatihan dinilai efektif karena pengetahuan, sikap dan keterampilan peserta meningkat.
\end{abstract}

Kata kunci: Metode partisipatif; peningkatan nilai tambah; warung kopi berunsur edukasi

\section{INCREASE OF MARKETING MANAGEMENT CAPABILITY OF COFFEE SHOP AND COFFEE-BASED VALUE ADDED IN COOPERATIVE OF MARGAMULYA COFFEE PRODUCER}

\begin{abstract}
Currently the coffee shop business is popping up everywhere because the demand and habit of coffee in cafes / coffee shops to gather with friends, family or just a lifestyle is sweeping the country for all people, especially young people. To capture this opportunity, the Margamulya Coffee Producers Cooperative (KPKM) opened a coffee shop business unit with the name Gunung Tilu Coffee Shop. In addition, with the opening of a coffee shop business unit open to coffee farmers' mothers to entrust derivative products from good, non-food coffee. Therefore, it is felt necessary to train the marketing management of coffee shops so that cafes can compete and be sustainable. Likewise, training for farmers is needed for increasing the added value of coffee products. The method used is participatory empowerment, which includes training, mentoring, monitoring and evaluation with the goal being the manager of the Mount Tilu coffee shop and farm mothers and young women coffee farmers. The first step is tracking information for activities that will be made such as the need to increase the added value of coffee and the management of educational coffee shops. Furthermore, several times the material and skills training for value-added were given a number of speakers who invited lecturers other than lecturers and students as well as the provision of knowledge about the use of social media as a facility for promotion and material on making educational posters. The evaluation results showed that training was considered effective because the participants'knowledge, attitudes and skills improved.
\end{abstract}

Key words: Participatory methods; increased value added; coffee shops with educational elements

\section{PENDAHULUAN}

Berdasarkan UU No 25 thun 1992 koperasi adalah sebuah perkumpulan dari orang-orang yang bersatu secara sukarela untuk memenuhi berbagai bentuk kebutuhan dan aspirasi mereka melalui perusahaan yang dimiliki bersama dan dikendalikan secara demokratis. Bentuk kebutuhan dan aspirasi yang diperjuangkan bersama ini tidak hanya terkait dengan aspek ekonomi namun juga aspek sosial. Pengertiaan ini mengindikasikan bahwa koperasi bukan sekedar sebuah perusahaan, tapi dia dapat memiliki perusahaan (a co-operative is not a company but has a company), juga bukan organisasi yang menyalurkan bantuan social, aspek sosialnya lebih kepada bahwa koperasi kumpulan orang-orang yang mempunyai tujuan yang sama untuk bekerja sama saling menguatkan dalam rangka meningkatkan kesejahteraan. Demikian juga halnya dengan Koperasi Produsen Kopi Margamulya (KPKM) yang merupakan wadah untuk meningkatkan pendapatan petani kopi dan turut mendukung pemerintah dalam pengembangan kopi java preanger serta menjaga kelestarian alam dan lingkungan. Wilayah kerja KPKM ini bukan hanya meliputi Desa Margamulya saja namun juga ada kelompok tani dari desa Margaluyu yang bergabung ke KPKM. Saat ini ,jumlah anggota sudah mencapai lebih dari 140 orang sebagai modal utama koperasi sebagai penyedia cery yang akan diolah koperasi menjadi beberapa produk sesuai pesanan pelanggan KPKM. 
Untuk pemasaran KPKM sudah menjalin kemitraan dengan PT Taman Delta yang memberikan dukungan untuk mendapatkan sertifikat UTZ yang tujuan pasar kopinya untuk ekspor. Pengelolaan kopi untuk ekspor dan mendapatkan harga tinggi juga dilakukan di Kolombia karena memperhatikan lingkungan selain aspek sosial. (Gonzalez Perez and Santiago Gutierrez, 2012). Koperasi juga di beberapa Negara mampu meningkatkan akses petani kopi ke pasar yang lebih luas (Kramer, J.W. 2000 dalam Beuchelt and Zeller, 2012).

Produk utama KPKM adalah green bean, roasted bean dan grounded coffee. Selain produk utama yang dihasilkan KPKM sebenarnya terdapat peluang pengembangan usaha koperasi dari produk turunan lebih lanjut dari kopi seperti kue-kue, lilin aroma terapi, masker. Produk ini bisa untuk tujuan konsumsi keluarga ataupun untuk tujuan komersial. Untuk tujuan komersial sangat memungkinkan selain karena ketersediaan bahan baku juga dengan dibukanya usaha baru berupa kafe, produkproduk turunan dari kopi tersebut bisa dijual di kafe sebagai cemilan teman minum kopi atau sebagai salah satu oleh-oleh dari Pangalengan. Untuk unit usaha kafe ini juga karena masih baru nampaknya perlu penataan dan manajemen yang lebih baik sehingga kafe lebih dikenal, lebih menarik dan bernilai jual sehingga bisa berdayasaing dan berkelanjutan. Untuk itu maka diperlukan pembinaan dan penataan kafe yang baik dan menarik serta mengandung unsur edukasi sebagai ciri khas kafe atau warung kopi Gunung Tilu.

Berdasarkan uraian pada latar belakang, maka dapat dirumuskan masalah untuk kegiatan PKM ini yaitu:

(1) Koperasi Produsen Kopi Margamulya (KPKM) perlu upaya meningkatkan kesejahteraan anggotanya melalui peningkatan nilai tambah dari produk kopi baik berupa paangan maupun non pangan.

(2) Unit Usaha Kafe (warung kopi) Gunung Tilu perlu lebih dikkenalkan melalui promosi antara lain melalui media social (medsos) serta meningkatkan pengelolaannya denngan mengusung konsep warung kopi berunsur edukasi.

\section{Koperasi Produsen dan Perannya}

Dalam perekonmian Indonnesia, koperasi mempunyai peranan yang sangat penting, karena badan usaha ini di cita-citakan oleh bangsa Indonesia sebagai bangun usaha yang paling cocok. Sebagaimana yang dinayatakan oleh Undang-undang Nomor 25 tahun 1992 koperasi adalah organisasi ekonomi rakyat yang berwatak sosial, beranggotakan orang-oran atau badan-badan hukum koperasi yang merupakan tata susunan ekonomi sebagai usaha bersama berdasarkan atas asas kekeluargaan.

Peran koperasi hubungannya dengan anggota bisa dibagi peran ke dalam dan ke luar. Peran ke dalam adalah hubungan pelayanan, antara lain melayani keperluan anggota-anggotanya, misalnya dalam pengadaan bahan atau sarana produksi usaha anggotanya, penyediaan modal, pembinaan dan lain-lain yang sifatnya meningkatkan kapasitas sumber daya manusia dan usaha anggotanya. Peran ke luar, koperasi lebih kepada promosi usaha anggota serta pemasaran hasil usaha anggotanya. Peran ini tujuannya dalam rangka meningkatkan bargaining position anggota yang tergabung dalam koperasi, antara lain melalui kemitraan, pembuatan sertifikasi produk, dan lain-lain.

Peran koperasi sebagai kelembagaan yang dimiliki petani dapat mengurangi biaya transaksi, sebagaimana pendapat Shiferaw. et.al (2009) bahwa inovasi kelembagaan dapat mengurangi biaya transaksi dan meningkatkan koordinasi pasar (misalnya koperasi/ kelompok pemasaran/ tindakan kolektif/oganisasi petani) memiliki potensi untuk mengurangi dampak dari pasar tidak sempurna serta memungkinkan hubungan untuk input dan output terkoordinasi di pasar serta memanfaatkan fungsi pasar untuk petani kecil.

Koperasi juga berkewajiban untuk mempromosikan kepentingan petani sebagai anggotanya. sebagaimana tujuan utama dari organisasi produsen adalah untuk memberikan layanan yang mendukung produsen dalam kegiatan pertanian mereka, termasuk pemasaran hasil pertaniannya. Menurut Bijman and Wollni, 2008 dalam Karyani (2017) koperasi merupakan salah satu organisasi, dengan prinsip keanggotaan sukarela, yang didirikan untuk kepentingan ekonomi anggotanya dengan menyediakan layanan yang mendukung kegiatan pertanian, seperti tawar-menawar dengan pelanggan, memberikan input, memberikan bantuan teknis, menyediakan pengolahan dan pemasaran jasa.

Koperasi sebagai organisasi produsen dengan fungsi utama ekonomi dapat dibagi menjadi dua kategori. Satu kategori termasuk organisasi-organisasi yang telah terintegrasi maju ke dalam rantai nilai dengan produk pertanian pengolahan dan/atau pemasaran, atau yang terintegrasi mundur dengan membeli dan/atau memproduksi input pertanian.

Lebih lanjut dinyatakan bawa koperasi dan asosiasi petani adalah bentuk organisasi produsen (pertanian) yang telah memainkan peran penting dalam memberikan dukungan kepada petani untuk mengkonversi produksi petani dan mengadopsi standar kualitas (Varangis et.al., 2003; Bacon, 2005). Selain itu menurut Verhaegen and Huylenbroeck (2001), lembaga-lembaga seperti koperasi secara substansial dapat mengurangi biaya pengumpulan informasi. Dalam hal ini koperasi dapat memainkan peran penting dalam memungkinkan petani untuk mengakses pasar khusus (Blackman et. al., 2005).

\section{Peningkatan Nilai Tambah Koperasi Produsen Kopi Margamulya}

Nilai tambah (value added) adalah pertambahan nilai suatu komoditas karena mengalami proses pengolahan, pengangkutan ataupun penyimpanan dalam suatu 
produksi. Dalam proses pengolahan nilai tambah dapat didefinisikan sebagai selisih antara nilai produk dengan nilai biaya bahan baku dan input lainnya, tidak termasuk tenaga kerja. Sedangkan marjin adalah selisih antara nilai produk dengan harga bahan bakunya saja. Dalam marjin ini tercakup komponen faktor produksi yang digunakan yaitu tenaga kerja, input lainnya dan balas jasa pengusaha pengolahan (Hayami et al, 1987).

Tujuan analisis nilai tambah adalah untuk mengukur balas jasa yang diterima pelaku usaha dan kesempatan kerja yang dapat diciptakan oleh sistem komoditi tersebut. Nilai tambah merupakan hasil pengurangan harga jual dikurangi biaya pembelian bahan baku dan sering kali digunakan sebagai titik fokus untuk analisis biaya (Porter, 1994). Menurut Trienekens (2011), nilai tambah yang tercipta di setiap pelaku rantai nilai akibat adanya aktivitas atau tahapan yang berbeda di setiap pelakunya. Nilai tambah yang dimaksud Trienekens (2011) berhubungan dengan kualitas yang tinggi, biaya yang lebih murah, waktu pengiriman, inovasi, dan lain-lain.

Menurut Trienekens (2011), salah satu faktor penting yang mempengaruhi nilai tambah produk pertanian adalah kualitas. Kualitas produk pertanian terbagi menjadi dua, yaitu karakteristik intrinsik (seperti warna, ciri fisik, dan rasa) dan karakteristik ekstrinsik (seperti fair trade dan pertanian organik). Nilai tambah dalam rantai nilai dipengaruhi oleh tujuan pasar dan jumlah aktor dalam rantai nilai.

Kegiatan pengolahan kopi dimulai saat anggota menyetorkan hasil panen kopi petik merahnya (cherry). Kegiatan pengolahan kopi di Koperasi Produsen Kopi "Margamulya" menerapkan metode pengolahan basah (wet processing) yang terdiri dari pengelupasan kulit luar dengan mesin pulper, kemudian kopi di difermentasikan selama 12 jam untuk mengh-ilangkan lendir pada biji kopi. Setelah itu kopi yang dihasilkan dinamakan gabah kopi, yang kemudian dicuci dengan menggunakan washer. Setelah gabah kopi bersih dari berbagai kotoran kemudian biji kopi tersebut dijemur sampai kadar airnya $30 \%$. Setelah di jemur, kopi tersebut dimasukan kedalam mesin huller untuk di hilangkan kulit tanduk dan arinya sehingga dihasilkan green bean. Kemudian kopi tersebut dijemur kembali sampai kadar air mendekati 12\% dan barulah dihasilkan green bean kopi. Green bean kopi tersebut kemudian disimpan dalam karung dan disimpan di gudang penyimpanan. Selain menghasilkan green bean, KPKM juga memproduksi kopi dalam bentuk roasted bean (kopi sangray) dan grounded coffee (kopi bubuk). Kegiatan pengolahan ini dioperasikan oleh koperasi.

Ada beberapa produk yang bisa diusahakan petani selain sebagai penyedia cery untuk koperasi yang bersumber dari kopi untuk meningkatkan nilai tambah yang pada gilirannya dapat meningkatkan pendapatan keluarga. Produk tersebut dapat berupa penganan maupun non penganan yang memanfaatkan kopi sebagai bahan pokoknya.

\section{METODE}

Tahap Monitoring dan evaluasi Metode yang digunakan dalamkegiataniniadalahmetodepemberdayaan partisipatif, yang berbentuk penyuluhan, pelatihan dan pendampingan. Pelibatan peran serta khalayak sasaran dilakukan sejak penyusunan rencna kegiatan berdasarkan kebuttuhan mereka.

Kegiatan PKM Hibah Internal Unpad (HIU) dilaksanakan pada kurun waktu sekitar 5 bulan, bulan MeiNovember 2018, ditujukan untuk meningkatkan kinerja bisnis Koperasi terutama unit bisnis kafe dan manfaaat adanya nilai tambah bagi keluarg petani dari pengolahan lanjut kopi. Beberapa kegiatan yang dilakukan dalam pemecahan masalah diantaranya:

Tahapan Kegiatan Pengabdian Kepada Masyarakat (rincian kegiatan) sesuai dengan agenda waktu yang tersedia dan disajikan pada Tabel 1.

Tahapan Kegiatan Pengabdian Kepada Masyarakat (Rinci kegiatan Pengabdian Kepada Masyarakat sesuai dengan agenda waktu yang tersedia.

Selanjutnya untuk mengukur indikator keberhasilan dapat dilihat pada Tabel 2

\section{HASIL DAN PEMBAHASAN}

Menurut Totok dan Soebianto (2013), keberhasilan kegiatan PPM diukur berdasarkan (1) tingkat partisipasi peserta dalam keseluruhan kegiatan; (2) perubahan perilaku yang meliputi penegetahuan, sikap dan keterampilan; (3) kualitas produk yang dihasilkan; (4) kesesuai materi pelatihan dengan kebutuhan audience. Perubahan pengetahuan diukur dari pre test dan post test. Sikap dilihat dari semangat mengikuti seluruh rangkaian kegiatan PPM. Keterampilan dilihat dari kemampuan mempraktekan upaya peningkatan nilai tambah .

Tabel 3. Hasil yang Dicapai Setelah Kegiatan PPM Mono Tahun 2018

\begin{tabular}{|c|c|c|c|}
\hline \multirow{2}{*}{ No } & \multirow{2}{*}{ Target } & \multicolumn{2}{|c|}{ Indikator Keberhasilan } \\
\hline & & Sebelum & Setelah \\
\hline 1 & $\begin{array}{l}\text { Pengetahuan, } \\
\text { sikap dan } \\
\text { keterampilan } \\
\text { mengenai } \\
\text { peningkatan nilai } \\
\text { tambah dari kopi } \\
\text { selain sebagai } \\
\text { minuman }\end{array}$ & $\begin{array}{l}\text { Pengetahuan,sikap } \\
\text { dan keterampilan } \\
\text { mengenai upaya } \\
\text { pengolahan } \\
\text { lanjutan dari } \\
\text { kopi menjadi } \\
\text { produk lain selain } \\
\text { minuman masih } \\
\text { rendah }\end{array}$ & $\begin{array}{l}\text { Pengetahuan, } \\
\text { sikap dan } \\
\text { keterampilan } \\
\text { ibu-ibu mengenai } \\
\text { pengolahan } \\
\text { kopi menjaddi } \\
\text { produk lain } \\
\text { selain minuman } \\
\text { meningkat }\end{array}$ \\
\hline 2 & $\begin{array}{l}\text { Pengetahuan, } \\
\text { sikap dan } \\
\text { keterampilan } \\
\text { pengelola kafe } \\
\text { mengenai } \\
\text { manajemen } \\
\text { pemasaran kafe } \\
\text { (warung kopi) } \\
\text { berunsur edukasi }\end{array}$ & $\begin{array}{l}\text { Pengetahuan,sikap } \\
\text { dan keterampilan } \\
\text { mengenai } \\
\text { manajemen } \\
\text { pemasaran kafe } \\
\text { (warung kopi) } \\
\text { berunsur edukasi } \\
\text { masih rendah }\end{array}$ & $\begin{array}{l}\text { Pengetahuan, } \\
\text { sikap dan } \\
\text { keterampilan } \\
\text { pengelola } \\
\text { mengenai } \\
\text { manejemen } \\
\text { pemasaran } \\
\text { warung kopi } \\
\text { berunsur edukasi } \\
\text { meningkat }\end{array}$ \\
\hline
\end{tabular}


Tabel 1. Kegiatan dan Metode Pelaksanaan PKM

\section{No. Rencana Kegiatan}

1. Tahap persiapan

- Pembuatan proposal

- Pembuatan undangan pelatihan

- Pembuatan modul pelatihan

- Mencari nara sumber

2. Tahap pelaksanaan:

- Pemberian materi pelatihan

- Pratek pembuatan kue secara partisipatif

\section{Tahap monitoring:}

Memantau perkembangan hasil pelatihan partisipatif setelah pelaksanaan dan sebelum dilakukan penilaian

4. Tahap evaluasi: cara berdiskusi setelah proses terhadap hasil pelatihan monitoring

5. Tahap pelaporan: Dosen menyelesaikan laporan

- Menyusun laporan kegiatan kegiatan PKM dengan sebaikPKM

- Memberikan laporan hasil kegiatan

\section{Keterlibatan dalam kegiatan}

Mahasiswa

Mahasiswa memberikan dengan petani dan Pengurus/ memberikan informasi yang Pengelola Koperasi di Desa dibutuhkan Margamulya.

Mahasiswa membantu dosen dan nara sumber dalam pembuatan berbagai penganan berbahan kopi

Mahasiswa membantu dosen dalam memonitor perkembangan hasil pelatihan yang dilakukan secara beerkelompok

Mahasiswa membantu dosen melakukan evaluasi hasil pelatihan
Petani dan Pengurus/pengelola KPKM berpartisipasi aktif dalam pelaksanaan Pelatihan

Petani dan Pengurus/ Pengelola berperan dalam mengimplementasi pelatihan

Petani dan Pengurus/Pengelola dapat memanfaatkan pelaksanaan diskusi dengan cermat.

Tabel 2. Indikator keberhasilan kegiatan (utama dan penunjang)

\begin{tabular}{clll}
\hline No & \multicolumn{1}{c}{ Indikator } & \multicolumn{1}{c}{$\begin{array}{c}\text { Base Line } \\
\text { (sebelum kegiatan) }\end{array}$} & Pencapaian \\
\hline 1 & $\begin{array}{l}\text { Peningkatan pengetahuan tentang pentingnya } \\
\text { upaya peningkatan nilai tambah kopi menjadi } \\
\text { berbagai produk yang bisa meningkatkan } \\
\text { pendapatan keluarga petani kopi. Selain itu } \\
\text { bisa lebih menyemarakkan warung kopi } \\
\text { dengan varian produk berbasis kopi. }\end{array}$ & $\begin{array}{l}\text { Belum mengetahui teknik dan pentingnya } \\
\text { upaya peningkatan nilai tambah }\end{array}$ & $\begin{array}{l}\text { Petani dan pengurus//pengelola } \\
\text { mengetahui pentingnya peningkatan } \\
\text { nilai tambah dari kopi }\end{array}$ \\
2 & $\begin{array}{l}\text { Peningkatan keterampilan membuat produk } \\
\text { berbahan kopi (penganan dan non penganan) }\end{array}$ & $\begin{array}{l}\text { Belum terampil melakukan pembuatan } \\
\text { produk berbahan kopi }\end{array}$ & $\begin{array}{l}\text { Ibu tani/petani terampil melakukan } \\
\text { pembuatan produk berbahan kopi }\end{array}$ \\
& $\begin{array}{l}\text { Peningkatan pengetahuan dan keterampilan } \\
\text { mengenai cara mengelola dan memasarkan } \\
\text { produk kafe }\end{array}$ & $\begin{array}{l}\text { Belum mengetahui dan terampil } \\
\text { mengenai cara mengelola dan } \\
\text { memasarkan produk kafe }\end{array}$ & $\begin{array}{l}\text { Pengurus/pengelola koperasi } \\
\text { mengetahui dan terampil mengenai } \\
\text { cara mengelola dan memasarkan } \\
\text { produk kafe }\end{array}$ \\
\hline
\end{tabular}

Produk makanan yang dihasikan dapat dilihat pada Gambar 1 berikut ini:

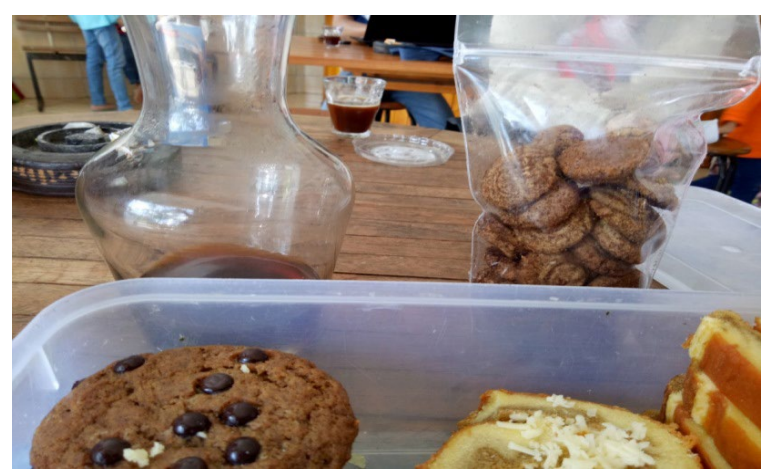

\section{Gambar 1. Produk makanan berbahan baku kopi}

Selanjutnya kegiatan peningkatan nilai tambah dari kopi untuk produk non makanan berbahan kopi dapat dilihat pada Gambar 2

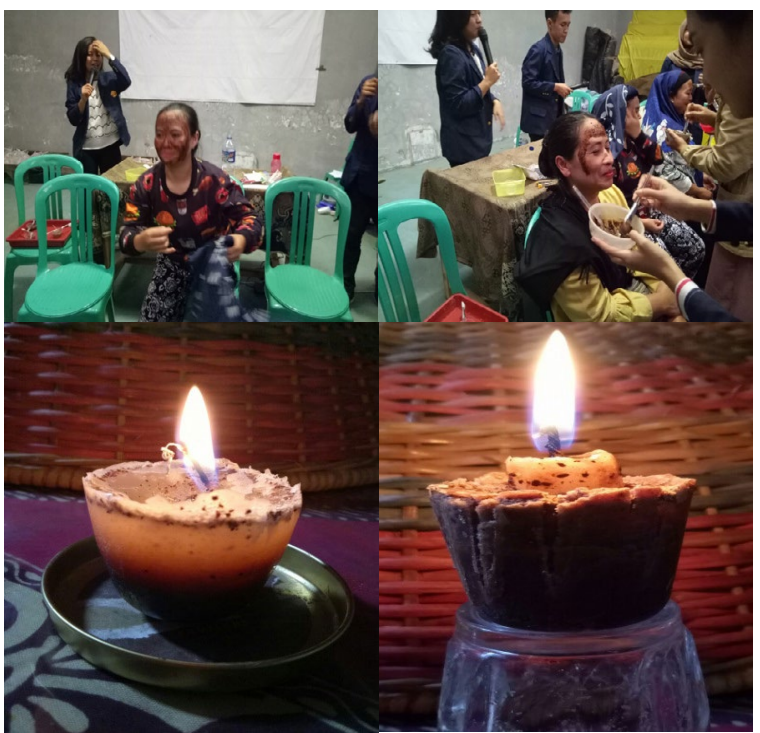

Gambar 2. Kegiatan Pelatihan dan Lilin Aroma Terapi Berbahan Kopi 
Adapun untuk promosi pemasaran warung kopi berunsur edukasi sudah dibuat poster yang memberikan penjelasan proses pembuatan kopi. Tujuannya agar pengunjung memahami perjalanan proses pembuatan kopi sejak petani sampai kopi siap jual (Gambar 3)

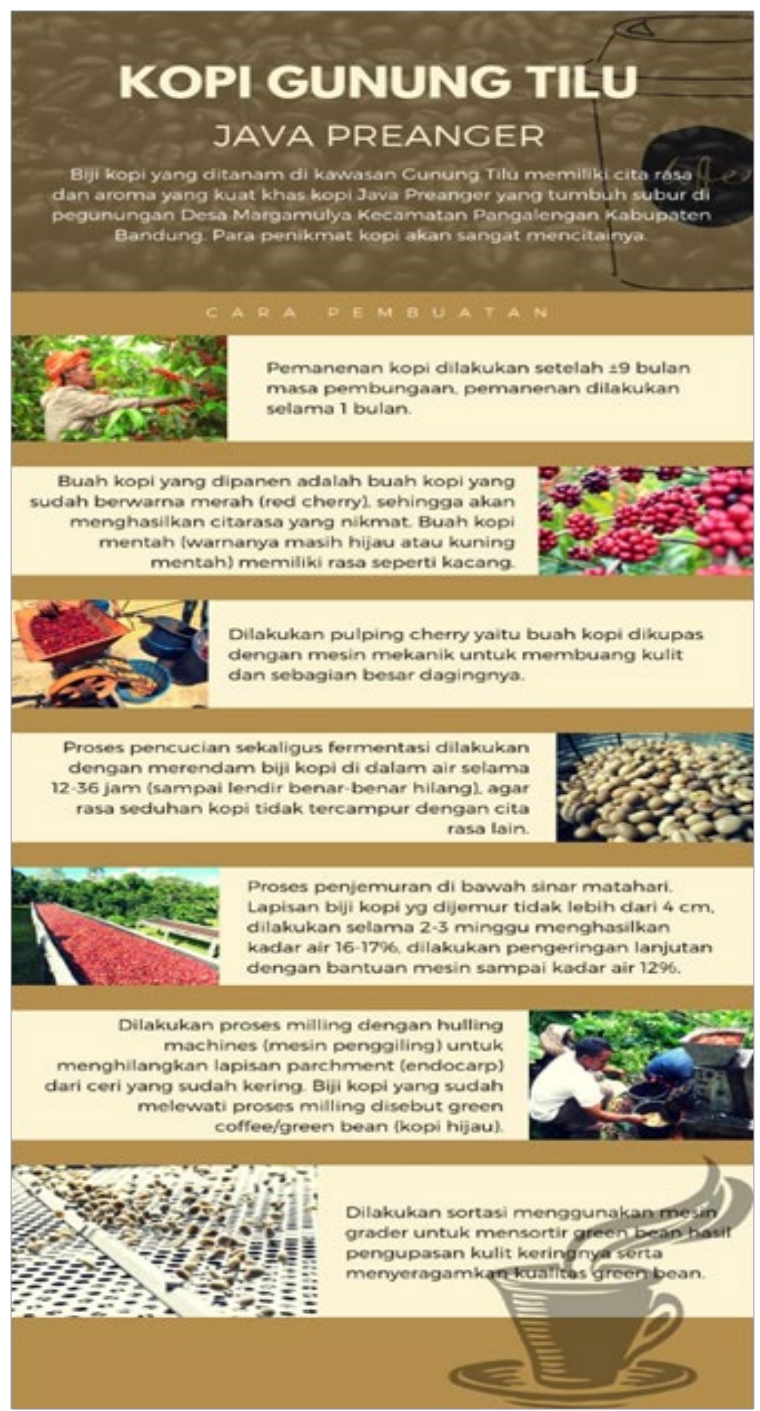

Gambar 3. Proses pengolahan Kopi Java Preanger di KPKM

Adapununtukinstagram sebagaiajang promosi dapat dilihat pada instagram dengan nama KPKMPangalengan serta youtube dengan pranala :https://youtu.be/shrop W2mtTE. Kegiatan PKM ini dipandang baik, para peserta terlihat sangat antusias dalam mengikuti kegiatan penyuluhan/pelatihan peningkatan nilai tambah kopi dan manajemen pemasaran usaha warung kopi. Tingkat kehadiran sebesar 90 persen dari target yang direncanakan. Hasil evaluasi menunjukkan bahwa pemahaman peserta mengenai peningkatan nilai tambah kopi menjadi produk lain selain minuman meningkat, demikian juga emahaman pengelola tentang mmanajemenn kafe yang berunsur edukasi menningkat.

Faktor pendorong kegiatan PKM ini adalah antusiasme yang tinggi dari para peserta dalam berpartisipasi aktif mengikuti semua sesi acara, adanya motivasi yang tinggi dari pengurus koperasi untuk meningkatkan kemampuan manajemen warung kafe scara lebih terkonsep sebagai kafee yang memiliki unsur edukasi.

Program PKM Hibah Internal Unpad (HIU) yang judul Peningkatan Kemampuan Manajemen Pemasaran Coffee Shop dan Nilai Tambah Pangan Berbahan Baku Kopi Di Koperasi Produsen Kopi Margamulya (KPKM) diharapkan memiliki keberlanjutan sebagai upaya dalam pengembangan agribisnis kopi java preanger berkelanjutan. Beberapa kegiatan yang bisa dilakukan diantaranya:

1. Pendampingan koperasi produsen kopi Margamulya dalam peningkatan kualitas pelayanan koperasi kepada para anggotanya.

2. Pendampingan dalam pengembangan unit bisnis warung kopi dengan mengembangkan berbagai varian produk yang bisa dipasarkan di warung kopi dengan tammpilan menarik yng bisaa dijadikan sebagai oleeholeh pengunjung kafe.

\section{SIMPULAN}

Kegiatan PKM ini telah meningkatkan pengetahuan, sikap dan keterampilan pengurus/pengelola KPKM dalam manajemen pemasaran kafe (warung kopi) berunsur edukasi, serta meningkatkkan pengetahuan, sikap dan keterampilan dalam menningkatkkan nilai tambah kpi menjadi produk lain selain kopi

Secara jangka panjang dengan rencana koperasi untuk mengembangkan desa wisata kopi maka kemampuan peningkatan nilai tambah serta kemampuan manajemen kafe yang lebih baik akan dapat menunjang kelancaran rencana bisnisnya.

Apabila program ini sudah selesai dilaksanakan dan dampaknya positif, serta berdasarkan analisis prognosisnya positif, maka program ini dapat dilanjutkan dengan kegiatan:

1. Untuk menyiapkan koperasi sebagai center of point dari desaa wisata maka perlu ada keberlanjutan pelatihan mengenai penangan produk seperti GMP (Good Manufacturing Practice), GHP (Good Handling Product), dll

2. Selain penanganan produk, manajemen koperasi juga dalam menyiapkan sebagai eksportir perlu pengetahuan dan keterampilan berkomunikasi bisnis dengan importer dari luar negeri.

3. Petani/ibu tani juga perlu terus didampingi dalam pengembangan produk dalam upaya meningkatkn nilai tambah sehingga pada gilirannya bsa meningkatkan penndapatan keluarganya.

\section{UCAPAN TERIMAKASIH}

Pada kesempatan ini Tim PKM mengucapkan terima kasih kepada DRPM Unpad yang telah menyelenggarakan dan memberikan hibah internal Unpad untuk 
kegiatan PKM sejalan dengan penelitian yang sedang berlangsung di lokasi penelitian sehingga kemanfaatan penelitian terasa langsung oleh kelompok sasaran.

\section{DAFTAR PUSTAKA}

Bacon, C., 2005. Confronting The Coffe Crisis : Can Fair Trade, Organic, and Specialty Coffees Reduce Small-Scale Farmer Vulnerability in Northern Nicaragua? World Development 33 (3): 497-511.

Beuchelt,Tina D and Manfred Zeller, 2012. The role of cooperative business models for the success of smallholder coffee certification in Nicaragua: A comparison of conventional, organic and OrganicFairtrade certified cooperatives. Renewable Agriculture and Food Systems: 28(3); 195-211

Blackman, A., Albers, H., Avalos-Sartorio, B. and Crooks, L., 2005. Deforestation and shade coffee in Oaxaca, Mexico - Key research findings. Discussion Paper 05-39, Resources for the Future, Washington, DC.

Gonzalez-Perez and Santiago Gutierrez, 2012. Cooperation in coffee markets: the case of Vietnam and Colombia. Journal of Agribusiness in Developing and Emerging Economies Vol. 2 No. 1, 2012. pp. 57-73.

Hayami, Y. et all. 1987. Agricultural marketing and Processing in up land Java. A perspective from a sunda Village. Bogor.CGPRT Centre.

Karyani, 2017. Peningkatan Kemampuan Kapasitas Manajemen Keuangan Koperasi Produsen Kopi
Margamulya (Kpkm) Berbasis Aplikasi. Jurnal Pengabdian Kepada Masyarakat, Dharma Karya. Universitas Padjadjaran.Vol. 1, No. 3, Juni 2017: $154-163$.

Porter, Michael. 1994. Keunggulan Bersaing: Menciptakan dan Mempertahankan Kinerja Unggul. Terj. Binarupa Aksara. Jakarta:Binarupa Aksara.

Shiferaw, B., Gideon Obare, Geoffrey Muricho, and Said Silim. 2009. Leveraging Institutions for Collective Action to Improve Markets for Smallholder Producers in Less-Favored Areas. Afjare (3) 1: 18 pp.

Trienekens, J.H.. 2011. Agricultural Value Chains in Developing Countries : A Framework To Analysis. International Food and Agribusiness Management Review, Volume 14, Issue 2. Belanda:Wagening University.

Totok Mardikanto dan Poerwoko Soebianto. 2013. Pemberdayaan Masyarakat dalam Perspektif Kebijakan Publik. Alfabeta Bandung

Varangis, P., P. Siegel, D. Giovannucci, and B. Lewin,. 2003. Dealing with The Coffee Crisis in Central America : Impacts and Strategies. Policy Research Working Papers (2993). The World Bank. Washington, D.C.

Verhaegen, I. and G. van Huylenbroeck. 2001. Costs and Benefits for Farmers Participating in Innovative Marketing Channels for Quality Food Products, Journal of Rural Studies 17: 443- 456. 